\title{
UJI EFEKTIFITAS PENURUNAN KADAR KOLESTEROL SARI BUAH STROBERI (Fragaria $x$-ananassa Duchesne) TERHADAP TIKUS PUTIH JANTAN GALUR WISTAR
}

\section{TEST EFFECTIVENESS OF CHOLESTEROL REMEDY OF STRAWBERY FRUIT (Fragaria $x$-ananassa Duchesne) ON WHITE RATS GALUR WISTAR}

\author{
Iin Indawati, Siti Pandanwangi \\ Akademi Farmasi Muhammadiyah Cirebon \\ Jl. Cideng Indah no. 3 Cirebon
}

\begin{abstract}
ABSTRAK
Buah Stroberi (Fragaria x-ananassa Duch.) mengandung senyawa flavonoid.Kandungan senyawa flavonoid dalam Stroberi dapat mencegah penyakit jantung dengan membantu melebarkan pembuluh darah dan melawan penumpukan plak yang dapat menyebabkan penyumbatan pada arteri koroner. Penelitian ini bertujuan untuk mengetahui efektifitas dan pada dosis berapa sari buah Stroberi (Fragaria $x$-anassa Duch.) dapat efektif sebagai penurun kadar kolesterol darah pada tikus putih jantan galur wistar. Pengujian dilakukan dengan mengamati penurunan kadar kolesterol dalam darah yang terdapat pada hewan uji setelah diberikan perlakuan. Hasil data stastistik anava one way menggunakan aplikasi SPSS versi 21.0 untuk program windows. Menunjukan bahwa sari buah Stroberi (Fragaria x-ananassa Duch.) mempunyai efektifitas sebagai penurun kadar kolesterol terhadap tikus putih jantan galur wistar yang sebelumnya diinduksi telur ayam ras dan lemak hewan. Sari buah Stroberi dosis 1,44 g/200 g tikus, 1,62 g/200 g tikus, dan 1,8 g/200 g tikus mempunyai efek menurunkan kadar kolesterol darah pada tikus putih jantan galur wistar.
\end{abstract}

Kata kunci: Uji Efektifitas, Penurunan Kadar Kolesterol, Sari Buah Stroberi (Fragaria x-ananassa Duch.), Tikus Putih Jantan Galur Wistar.

\begin{abstract}
Strawberries (Fragaria x-ananassa Duch.)Containing flavonoids. The content of flavonoid compounds in strawberries can prevent heart disease by helping to dilate blood vessels and fight the buildup of plaque that can cause a blockage in the coronary arteries. This study aims to evaluate the efficacy and at what dose Fruit Strawberry (Fragaria $x$-anassa Duch.) Can be effective as lowering blood cholesterol levels in male rats.Testing is done by observing the drop in cholesterol levels in the blood contained in the test animals after a given treatment. Results of statistical data is one way ANOVA using SPSS version 21.0 for Windows program. Showed that the juice Strawberries (Fragaria $x$-ananassa Duch.) Has a cholesterol-lowering effectiveness as against white male rats previously induced eggs and animal fat. Strawberry fruit juice dosage of $1.44 \mathrm{~g} / 200 \mathrm{~g}$ rat, $1.62 \mathrm{~g} / 200$ $\mathrm{g}$ rat, and $1.8 \mathrm{~g} / 200 \mathrm{~g}$ rat has the effect of lowering blood cholesterol levels in male rats.
\end{abstract}

Keywords:Effectiveness Test, Cholesterol Levels decline, Fruit juice strawberries (Fragaria xananassa Duch.), Rats Male Wistar. 


\section{PENDAHULUAN}

Kolesterol merupakan salah satu komponen lemak atau lipid. Lemak merupakan salah satu zat gizi yang sangat diperlukan oleh tubuh kita selain zat gizi lain, seperti karbohidrat, protein, vitamin, dan mineral. Kolesterol merupakan lemak yang berwarna kekuningan menyerupai lilin, yang penting sekali, asalkan tidak berlebihan.Kolesterol secara terus-menerus dibentuk atau disintesis didalam hati atau liver.Bahkan, sekitar $70 \%$ kolesterol dalam darah merupakan hasil sintesis didalam hati, sedangkan sisanya berasal dari asupan makanan.Kolesterol secara normal diproduksi sendiri oleh tubuh dalam jumlah yang tepat.Namun, kolesterol bisa meningkat jumlahnya karena asupan makanan yang berasal dari lemak hewani, telur, dan Junkfood atau disebut dengan makanan sampah.(Anies, 2015).Kadar kolesterol yang tinggi di dalam darah atau yang disebut dengan Hiperkolesterolemia merupakan salah satu dari beberapa faktor resiko utama penyakit jantung koroner (Anwar, 2004). Hiperkolesterolemia atau peninggian kadar kolesterol dalam darah yang tinggi merupakan salah satu faktor risiko yang paling utama untuk terjadinya penyakit jantung koroner selain faktor lainnya, seperti tekanan darah tinggi dan merokok. Sebab kadar kolesterol yang tinggi dapat mengganggu kesehatan, bahkan mengancam kehidupan manusia. Menurut hipotesis lipid kadar abnormal (hiperkolesterolemia) yaitu, konsentrasi yang lebih tinggi dari LDL dan konsentrasi yang lebih rendah HDL fungsional yang berkaitan erat dengan penyakit jantung karena memperomosikan pembangunan ateroma pada arteri (Aterosklerosis). Proses penyakit menyebabkan infrak miokard (serangan jantung), stroke, dan penyakit pembuluh darah perifer.Karena darah yang lebih tinggi LDL, terutama LDL konsentrasi yang lebih tinggi dan lebih kecil. Partikel LDL sering disebut "Kolesterol jahat".

Stroberi yang tergolong genus Fragaria terdiri dari banyak spesies yang dikenal secara empiris dapat membantu menurunkan darah salah satunya jenis Stroberi Fragaria x-ananassa Duch.Endang Peddyawati, MS, SpGK. Doktor spesialis gizi klinik dari RSUP Persahabatan menyatakan, pada Stroberi juga mengandung pektin yang dapat membantu menurunkan kadar kolesterol dalam darah. Sifat antioksidatif senyawa fitokimia dalam Stroberi dapat membantu menurunkan resiko terjadinya penyakit kardiovaskular yaitu dangan menghambat pembentukan kolesterol jahat (Bangun ,2013). Kandungan antosianin dalam Stroberi berguna sebagai antioksidan di dalam tubuh. Antosianin bekerja menghambat proses aterogenesis dengan mengoksidasi lemak jahat dalam tubuh, kemudian antosianin juga melindungi integritas sel endotel yang melapisi dinding pembuluh darah sehingga tidak terjadi kerusakan. kerusakan sel endotel merupakan awal mula pembentukan aterosklrosis. Selain itu antosianin juga dapat merelaksasi pembuluh darah untuk mencegah aterosklerosis dan penyakit kardiovaskular lainnya (Sri Kumalaningsih, 2006).Menurut Kwon (2007), antosianin membantu pengeluaran kolesterol dari jaringan perifer menuju hepar dan selanjutnya dikeluarkan melalui ekresi biller.

\section{METODE PENELITIAN}

\section{Alat}

Alat yang digunakan dalam penelitian ini, antara lain Juicer, sonde oral (tikus), timbangan digital, beaker glass, corong, mortar dan stemper, kain flanel, batang pengaduk, alat pengukur kolesterol (Accu check, stik kolesterol), pipet tetes, pisau, baskom, label, lakban, sarung tangan, masker, gelas ukur, botol $100 \mathrm{ml}$, kertas saring, kandang, alat injeksi, cawan penguap, kaki tiga dan pembakar spirtus.

\section{Bahan}

Bahan yang digunakan dalam penelitian ini berupa buah stroberi segar(Fragaria $x$-ananassa Duch.), Simvastatin $10 \mathrm{mg}, \mathrm{CMC}$, Aquadest, lipid hewan, telur ayam ras, PTU (Propiltiourasil).

\section{Jalannya Penelitian}

\section{Pembuatan Sampel}

Sari buah adalah suatu cairan yang diperoleh dari memeras buah, baik di saring maupun tidak, yang tidak mengalami fermentasi dan dimaksudkan untuk minuman segar yang langsung dapat diminum (Caya dan Andi, 2007).Buah Stroberi (Fragaria x-ananassa Duch.) segar yang telah masak 
di peroleh dari pasar di cuci bersih dengan air kemudian di timbang masing-masing sebanyak 1,44 g, $1,62 \mathrm{~g}$, dan 1,80 g. Metode penyarian buah stroberi ini dilakukan dengan cara sederhana yaitu dengan cara menghaluskan buah stroberi segar (Fragaria x-ananassa Duch.) dan penambahan air sesuai dengan volume yang telah ditentukan (lampiran) kedalam mesin juicer. Setelah itu hasil terlebih dahulu disaring, sehingga diperoleh hasil sari buah stroberi (Fragaria $x$-ananassa Duch.) dalam bentuk sari buah yang masih segar.

\section{Persiapan hewan uji}

Hewan yang digunakan dalam penelitian ini adalah tikus putih jantan (Rattus norvegicus) sebanyak 15 ekor dengan berat badan dewasa rata-rata 200-300 gram, dengan umur kurang lebih tiga bulan. Masing-masing tikus dibagi menjadi lima kelompok secara acak, dalam tiap kelompok terdiri dari tiga tikus putih jantan.

\section{Uji efektivitas penurunan kadar kolesterol}

Tikus sebanyak 15 ekor dibagi dalam lima kelompok secara acak sehingga tiap kelompok terdiri dari 3 ekor tikus putih jantan (Rattus norvegicus) Selama tujuh hari tikus diadaptasi dengan lingkungan tempat penelitian. Setelah masa adaptasi selesai semua tikus putih jantan (Rattus norvegicus) diambil darahnya melalui ekor untuk pemeriksaan kadar kolesterol awal. Berikutnya dilakukan pemberian induksi Hiperkolesterol dan penambahan propiltiourasil pada masing-masing tikus putih jantan (Rattus norvegicus) yang sebelumnya dipuasakan selama 12 jam.Tikus diinduksi pakan hiperkolesterol selama tujuh hari. Pada hari ketujuh dilakukan pengecekan kembali kadar kolesterol setelah induksi. Jika hasil pengecekan setelah induksi pakan hiperkolesterol tikus mengalami kenaikan kolesterol > 200 maka dilakukan perlakuan dengan pemberian zat uji sebanyak 3 $\mathrm{ml}$ terhadap masing-masing kelompok tikus putih jantan (Rattus norvegicus) secara oral menggunakan sonde, diantaranya Kelompok I diberikan Sari buah stroberi dosis 1,44 g/ 200 g tikus (X1), Kelompok II diberikan Sari buah stroberi dosis 1,62 g/ $200 \mathrm{~g}$ tikus (X2) ,Kelompok III diberikan Sari buah stroberi dosis 1,80 g/ $200 \mathrm{~g}$ tikus (X3), Kelompok IV diberikan Suspensi simvastatin sebagai kontrol positif (K+), dan pada Kelompok V diberikan Aquadest diberikan kontrol negatif (K-).

Pada hari ke-14 pemberian zat, dilakukan pengukuran kembali kadar kolesterol tikus Putih jantan (Rattus norvegicus). Dengan catatan pemberian zat uji masih tetap dilakukan hingga pengecekan kadar kolesterol akhir. Pada hari ke-21 dilakukan pengukuran kembali kadar kolesterol tikus putih jantan (Rattus norvegicus). Pada hari ke-28 dilakukan pengukuran kembali kadar kolesterol tikus putih jantan (Rattus norvegicus). Sehingga di peroleh kadar kolesterol seluruh tikus putih jantan (Rattus norvegicus) sebagai data hasil pengamatan. Melakukan analisis data kolesterol dari masingmasing kelompok tikus jantan (Rattus norvegicus) sebelum perlakuan dan sesudah dengan menggunakan perhitungan stastistik uji ANOVA satu arah dan uji t-test.

\section{Analisis Statistik}

Data dianalisis dengan aplikasi SPSS, terlabih dahulu data yang di peroleh di uji Normalitas dan Homogenitasnya agar data tersebut bisa dianalisa dengan uji Anova satu arah.Anova satu arah bertujuan untuk membuktikan hipotesis yang telah dibuat apakah terdapat efektifitas atau tidak. Kemudian setelah itu dilanjutkan dengan uji t-test yang bertujuan untuk menguji atau membandingkan perlakuan mana yang memiliki signifikan yang akurat (Sarwono, 2008) 


\section{HASIL DAN PEMBAHASAN}

Uji Kadar Penurunan Kolestrol

Tabel IData hasil pengukuran kadar kolesterol kelompok X1 pemberian sari buah Stroberi dengan dosis $1,44 \mathrm{~g} / 200 \mathrm{~g}$ tikus.

\begin{tabular}{|c|c|c|c|c|c|c|c|}
\hline \multirow[b]{2}{*}{ Kelompok uji } & \multirow[b]{2}{*}{$\begin{array}{l}\text { No. } \\
\text { Tikus }\end{array}$} & \multirow[b]{2}{*}{$\begin{array}{c}\text { BB. } \\
\text { Tikus } \\
\text { (gram) }\end{array}$} & \multirow[b]{2}{*}{$\begin{array}{c}\text { Kadar } \\
\text { kolesterol } \\
\text { awal } \\
(\mathbf{m g} / \mathbf{d l})\end{array}$} & \multicolumn{4}{|c|}{ Kadar kolesterol setelah perlakuan } \\
\hline & & & & $\begin{array}{c}\text { Kadar } \\
\text { kolesterol } \\
\text { setelah } \\
\text { induksi }\end{array}$ & $\begin{array}{c}\text { Hari } \\
\text { ke-14 }\end{array}$ & $\begin{array}{r}\text { Hari } \\
\text { ke-21 }\end{array}$ & $\begin{array}{c}\text { Hari } \\
\text { ke-28 }\end{array}$ \\
\hline \multirow{3}{*}{$\begin{array}{l}\text { Kelompok } \\
\text { Tikus X1 }\end{array}$} & 1 & 200 & 140 & 230 & 222 & 134 & 120 \\
\hline & 2 & 246 & 132 & 195 & 186 & 164 & 134 \\
\hline & 3 & 290 & 116 & 234 & 182 & 179 & 141 \\
\hline Jumlah & & & 388 & 659 & 590 & 477 & 395 \\
\hline Rata-rata & & & 129,33 & 219,66 & 196,66 & 159 & 131,66 \\
\hline
\end{tabular}

Tabel II. Data hasil pengukuran kadar kolesterol kelompok X1 pemberian sari buah Stroberi dengan dosis $1,62 \mathrm{~g} / 200 \mathrm{~g}$ tikus.

\begin{tabular}{lccccccc}
\hline Kelompok uji & $\begin{array}{c}\text { No. } \\
\text { Tikus }\end{array}$ & $\begin{array}{c}\text { BB } \\
\text { Tikus } \\
\text { (gram) }\end{array}$ & $\begin{array}{c}\text { Kadar } \\
\text { kolesterol } \\
\text { awal (mg/dl) }\end{array}$ & \multicolumn{3}{c}{ Kadar kolesterol setelah perlakuan } \\
\cline { 5 - 8 } & & & & $\begin{array}{c}\text { Kadar } \\
\text { kolesterol } \\
\text { setelah } \\
\text { induksi }\end{array}$ & $\begin{array}{c}\text { Hari } \\
\text { ke-14 }\end{array}$ & $\begin{array}{c}\text { Hari } \\
\text { ke- } \\
\mathbf{2 1}\end{array}$ & $\begin{array}{c}\text { Hari } \\
\text { ke-28 }\end{array}$ \\
\hline Kelompok & 1 & 237 & 206 & 271 & 179 & 145 & 109 \\
Tikus X2 & 2 & 210 & 199 & 227 & 192 & 161 & 133 \\
& 3 & 237 & 128 & 219 & 188 & 144 & 109 \\
Jumlah & & & 533 & 717 & 559 & 450 & 351 \\
\hline Rata-rata & & & 177,66 & 239 & 186,33 & 150 & 117 \\
\hline
\end{tabular}

Data yang digunakan dalam penelitian ini adalah data kadar kolesterol tikus yang diukur dengan menggunakan alat pengukur kadar kolesterol dengan merk dagang Nesco. Pengambilan darah dilakukan melalui pembuluh darah vena pada ekor tikus (Rattus norvegicus). Pengukuran kadar kolesterol dalam darah tikus dilakukan sebanyak lima kali untuk masing-masing kelompok. Yaitu, pengukuran awal kadar kolesterol dalam darah tikus yang dilakukan sebelum pemberian induksi, pengukuran kadar kolesterol darah kedua dilakukan setelah pemberian induksi pakan hiperkolesterol, pengukuran ketiga penurunan kadar kolesterol dalam darah tikus setelah pemberian zat uji dilakukan pada hari ke-14, 21, dan ke-28. 
Tabel III. Data hasil pengukuran kadar kolesterol kelompok X1 pemberian sari buah Stroberi dengan dosis $1,80 \mathrm{~g} / 200 \mathrm{~g}$ tikus.

\begin{tabular}{|c|c|c|c|c|c|c|c|}
\hline \multirow{2}{*}{ Kelompok uji } & \multirow{2}{*}{$\begin{array}{c}\text { No. } \\
\text { Tikus }\end{array}$} & \multirow{2}{*}{$\begin{array}{c}\text { BB } \\
\text { Tikus } \\
\text { (gram) }\end{array}$} & \multirow{2}{*}{$\begin{array}{c}\text { Kadar } \\
\text { kolesterol } \\
\text { awal (mg/dl) }\end{array}$} & \multicolumn{4}{|c|}{ Kadar kolesterol setelah perlakuan } \\
\hline & & & & $\begin{array}{c}\text { Kadar } \\
\text { kolesterol } \\
\text { setelah } \\
\text { induksi }\end{array}$ & $\begin{array}{c}\text { Hari } \\
\text { ke-14 }\end{array}$ & $\begin{array}{l}\text { Hari } \\
\text { ke-21 }\end{array}$ & $\begin{array}{r}\text { Hari } \\
\text { ke-28 }\end{array}$ \\
\hline \multirow{3}{*}{$\begin{array}{c}\text { Kelompok } \\
\text { Tikus X3 }\end{array}$} & 1 & 300 & 133 & 266 & 219 & 197 & 158 \\
\hline & 2 & 207 & 200 & 282 & 196 & 172 & 135 \\
\hline & 3 & 223 & 154 & 276 & 189 & 164 & 124 \\
\hline \multicolumn{2}{|c|}{ Jumlah } & & 478 & 824 & 604 & 533 & 417 \\
\hline \multicolumn{2}{|c|}{ Rata-rata } & & 162,33 & 274,66 & 201,33 & 177,66 & 139 \\
\hline
\end{tabular}

Hasil dari data pengukuran kadar kolesterol awal kisaran kadar kolesterol dalam darah tikus rata-rata masih dalam ambang darah normal sebelum diinduksi yaitu dibawah $200 \mathrm{mg} / \mathrm{dl}$. Setelah diinduksi kadar kolesterol dalam darah tikus putih mengalami kenaikan yaitu di atas $200 \mathrm{mg} / \mathrm{dl}$. Kemudian dilakukan perlakuan pada masing-masing kelompok hewan uji. Pada kelompok X1 diberikan sari buah Stroberi dosis 1,44 g /200 g tikus, kelompok X2 diberikan sari buah Stroberi dosis $1,62 \mathrm{~g} / 200 \mathrm{~g}$ tikus, kelompok X3 diberikan sari buah Stroberi dosis 1,80 g /200 g tikus. Sedangkan untuk kelompok kontrol positif diberikan simvastatin dan pada kelompok kontrol negatif diberikan aquadest.Zat uji diberikan dari hari ke-14 sampai dengan hari-28. Pemberian zat uji ini dilakukan empat jam sebelum pengecekan kadar kolesterol.

Tabel IV. Data hasil pengukuran kadar kolesterol kelompok kontrol positif (simvastatin).

\begin{tabular}{|c|c|c|c|c|c|c|c|c|}
\hline \multirow{2}{*}{ Kelompok uji } & \multirow{2}{*}{$\begin{array}{c}\text { No. } \\
\text { Tikus }\end{array}$} & \multirow{2}{*}{$\begin{array}{c}\text { BB Tikus } \\
\text { (gram) }\end{array}$} & \multirow{2}{*}{$\begin{array}{c}\text { Kadar } \\
\text { kolesterol } \\
\text { awal (mg/dl) }\end{array}$} & \multicolumn{5}{|c|}{ Kadar kolesterol setelah perlakuan } \\
\hline & & & & \multicolumn{2}{|c|}{$\begin{array}{c}\text { Kadar } \\
\text { kolesterol } \\
\text { setelah induksi }\end{array}$} & \multirow{2}{*}{$\begin{array}{r}\begin{array}{c}\text { Hari } \\
\text { ke-14 }\end{array} \\
192\end{array}$} & \multirow[t]{2}{*}{$\begin{array}{c}\text { Hari } \\
\text { ke- } \\
21 \\
\end{array}$} & \multirow{2}{*}{$\begin{array}{r}\begin{array}{r}\text { Hari } \\
\text { ke-28 }\end{array} \\
140\end{array}$} \\
\hline \multirow{3}{*}{$\begin{array}{l}\text { Kelompok } \\
\text { Tikus K+ }\end{array}$} & 1 & 180 & 178 & 297 & 235 & & & \\
\hline & 2 & 300 & 119 & 236 & 214 & 149 & & 124 \\
\hline & 3 & 250 & 148 & 247 & 195 & 139 & & 122 \\
\hline \multicolumn{2}{|c|}{ Jumlah } & & 445 & 780 & 644 & 480 & & 386 \\
\hline \multicolumn{2}{|c|}{ Rata-rata } & & 148,33 & 260 & 214,66 & 160 & & 28,66 \\
\hline
\end{tabular}

Berdasarkan data hasil pengukuran kadar kolesterol yang diperoleh dari hari ke hari dalam penelitian dapat diketahui bahwa sari buah Stroberi pada dosis 1,44 g/200 g tikus, 1,62 g /200 g tikus, dan $1,80 \mathrm{~g} / 200 \mathrm{~g}$ tikus dapat dikatakan efektif menurunkan kadar kolesterol dalam darah pada tikus putih jantan. 
Tabel V. Data hasil pengukuran kadar kolesterol kelompok K- Pemberian Aquadest.

\begin{tabular}{|c|c|c|c|c|c|c|c|}
\hline \multirow[t]{2}{*}{ Kelompok uji } & \multirow[t]{2}{*}{$\begin{array}{l}\text { No. } \\
\text { Tikus }\end{array}$} & \multirow{2}{*}{$\begin{array}{c}\text { BB } \\
\text { Tikus } \\
\text { (gram) }\end{array}$} & \multirow{2}{*}{$\begin{array}{c}\text { Kadar } \\
\text { kolesterol } \\
\text { awal } \\
(\mathrm{mg} / \mathrm{dl})\end{array}$} & \multicolumn{4}{|c|}{$\begin{array}{c}\text { Kadar kolesterol setelah pemberian } \\
\text { Aquadest }\end{array}$} \\
\hline & & & & $\begin{array}{c}\text { Kadar } \\
\text { kolesterol } \\
\text { setelah induksi }\end{array}$ & $\begin{array}{l}\text { Hari } \\
\text { ke-14 }\end{array}$ & $\begin{array}{l}\text { Hari } \\
\text { ke-21 }\end{array}$ & $\begin{aligned} \text { Hari } \\
\text { ke-28 }\end{aligned}$ \\
\hline \multirow{4}{*}{$\begin{array}{l}\text { Kelompok } \\
\text { Tikus K- }\end{array}$} & 1 & 198 & 166 & 200 & 271 & 290 & 290 \\
\hline & 2 & 270 & 140 & 216 & 235 & 266 & 282 \\
\hline & 3 & 250 & 109 & 215 & 227 & 247 & 325 \\
\hline & Jumlah & & 415 & 631 & 733 & 803 & 897 \\
\hline \multicolumn{3}{|c|}{ Rata-rata } & 138,33 & 210,33 & 244,33 & 267,6 & 299 \\
\hline
\end{tabular}

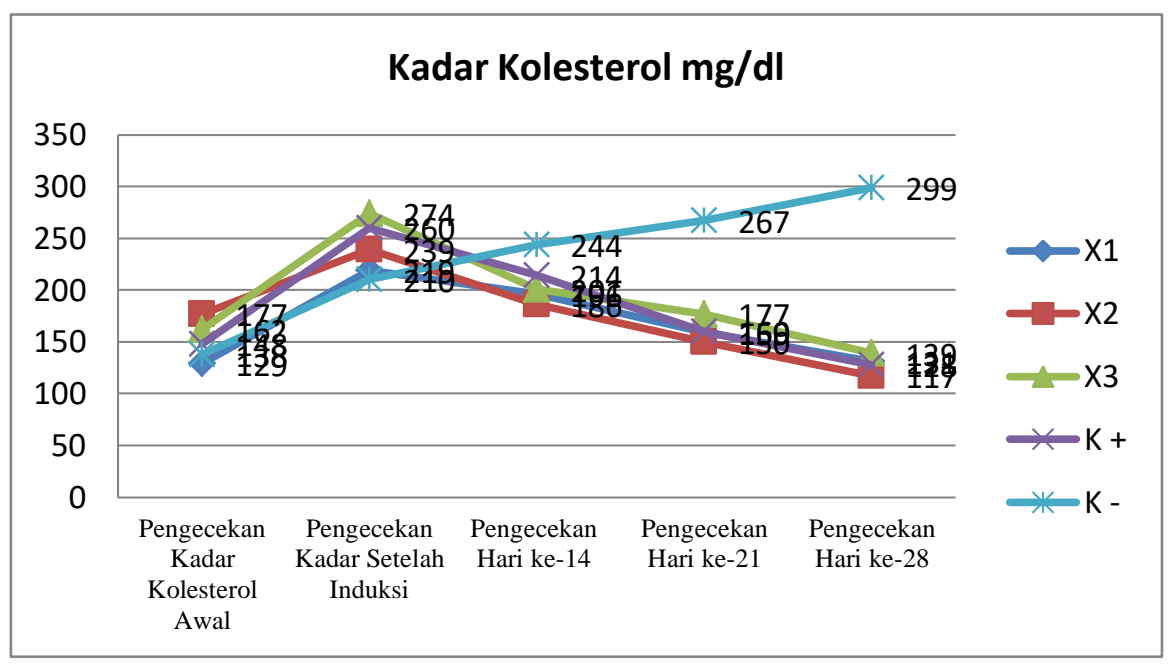

Gambar. I.Rata-Rata Kadar Kolesterol Pada Tikus Putih Jantan (Rattus norvegicus)

Keterangan:

X1 : Sari Buah Stroberi Dosis 1,44 g /200 g tikus.

$\mathrm{X} 2$ : Sari Buah Stroberi Dosis 1,62 g/200 g tikus.

X3 : Sari Buah Stroberi Dosis 1,80 g/200 g tikus.

$\mathrm{K}+\quad$ : Simvastatin (Kontrol Positif)

K- $\quad$ : Aquadest (Kontrol Negatif)

\section{Analisis Data}

\section{Uji Normalitas}

Berdasarkan hasil dari perhitungan uji normalitas diperoleh semua nilai (sig) $>0,01 .(0,523>$ $0,01 ; 0,955>0,01 ; 0,818>0,01 ; 0,605>0,01 ; 0,977>0,01)$. Maka H0 diterima, yang artinya data kadar kolesterol antar kelompok setelah perlakuan terdistribusi normal.

\section{Uji Homogenitas}

Dari hasil output yang didapat nilai signifikasi seluruh sampel dari uji Homogeneity of Variances didapat signifikan (sig) 0,765 >0,01. Maka sesuai dengan kriteria pengujian dapat disimpulkan bahwa H0 diterima, yang berarti asumsi kelima Varians populasi adalah sama (Homogen). 


\section{Uji ANOVA}

Tabel.VI. Hasil ANOVA Perubahan Kadar Kolesterol

\begin{tabular}{lccccc}
\hline & $\begin{array}{c}\text { Sum of } \\
\text { Squares }\end{array}$ & Df & $\begin{array}{c}\text { Mean } \\
\text { Square }\end{array}$ & F & Sig. \\
\hline Between Groups & 44780.133 & 4 & 11195.033 & 4.981 & .001 \\
Within Groups & 157317.867 & 70 & 2247.398 & & \\
Total & 202098.000 & 74 & & & \\
\hline
\end{tabular}

Dalam penelitian ini peneliti mengunakan taraf keyakinan $99 \%$, besar a $=0,01$, dan derajat kebebasan (df) diperoleh $\mathrm{df} 1=4, \mathrm{df} 2=70$ maka di peroleh $\mathrm{F}$ tabel $=3,599$. Melihat hasil (tabel 4.8) dihasilkan F hitung yaitu sebesar 4.981. Hal ini menunjukan hasil $\mathrm{F}$ hitung lebih besar dari nilai $\mathrm{F}$ tabel 4.981> 3,599 maka H0 ditolak dan H1 diterima. Artinya Sari Buah Stroberi terdapat efektifitas terhadap penurunan kadar kolesterol pada tikus putih jantan galur wistar.

\section{KESIMPULAN}

Pemberian Sari buah Stroberi (Fragaria x-ananassa Duch.) dengan dosis 1,44 g/200 g tikus mempunyai efektifitas menurunkan kadar kolesterol tikus secara signifikan. Pemberian Sari Buah Sroberi dosis 1,62 g/200 g tikus mempunyai efektifitas menurunkan kadar kolesterol tikus secara signifikan, Pemberian Sari buah Stroberi 1,80 g/200 g tikus mempunyai efektifitas menurunkan kadar kolesterol tikus secara signifikan. Melihat penurunan nilai total cholesterol (TC) pada semua kelompok, Sari buah Stroberi nyata mempunyai efek menurunkan kadar kolesterol, meskipun belum memberikan hasil yang sama dengan simvastatin.

\section{DAFTAR PUSTAKA}

Anies. 2015. Kolesterol dan Penyakit Jantung Koroner. Yogyakarta: Ar-ruzz Media.

Bangun, A. P.2013. Ensiklopedia Jus Buah dan Sayur Untuk Penyembuhan. Jakarta: Indonesia Publishing House

Bangun, A. P.2003. Terapi Jus \& Ramuan Tradisional untuk Kolesterol. Jakarta: Argomedia Pustaka. BPOM RI. 2012. ISO Indonesia Volume 47. Jakarta: PT. ISFI Penerbitan.

Cahyono, B. 2011.Sukses Budidaya Stroberi di Pot dan Perkebunan. Yogyakarta: Lily Publisher.

Darmono, S. 2011. Farmakologi Eksperimental. Jakarta: penerbit Universitas Indonesia (UI-Press).

Guyton A.C., Hall J.E. 1997. Buku Ajar Fisiologis Kedokteran.Edisi 9. Jakarta: Buku Kedokteran EGC

Hariadi. 2012. Peluang Jitu Berternak Tikus Putih. Yogyakarta: Pustaka Baru Press.

Kingham, K. 2009. Makan Oke Hidup Oke Dengan Kolesterol Tinggi. Jakarta: Erlangga.

Khairani, C dan Dalapati, A. 2007.Petunjuk Teknis Pengolahan Buah-Buahan. Departemen Pertanian: Sulawesi Tengah

Kumalaningsih, S. 2006. Antioksidan Alami. Surabaya: Trubus Agrisarana.

Natawidjaya, P. S. 1983. Mengenal Beberapa Binatang di Alam Sekitarnya. Jakarta: Pustaka Dian.

Notoatmojo, S. 2005. Metode Penelitian Kesehatan. Jakarta: Rinerka Cipta.

Nurcahyaningtyas, H. 2012. (Skripsi) Efek Antihiperlipidemia Susu Kacang Kedelai (Glycine Max (L.) Merr.)Pada Tikus Putih Jantan yang Diberi Diit Tinggi Kolesterol Dan Lemak.Skripsi. Depok: Universitas Indonesia. Hal.31-55.

Purwanti, S. 2012. (Skripsi) Efek Antihiperlipidemia Ekstrak Etanol 70\% buah Oyong (Luffa acutangula (L.)Roxb.)Pada Jenis Tikus Jantan yang Diberi Diit Tinggi Kolesterol dan Lemak.Skripsi. Depok: Universitas Indonesia. Hal.17-41. 
Riduwan. 2013. Dasar-dasar Statistika. Bandung: Alfabeta.

Rubenstein, David. 2007. Lecture Notes Kedokteran Klinis Edisi Keenam. Jakarta: Erlangga.

Saidin, M. 2002. Cholesterol Content of Food Originatinf From Animal Tissue. Litbangkes-Depkes RI. 27 (2).224-230.

Satuhu. 2004. Penanganan dan Pengolahan Pangan. Penebar Swadaya Jakarta.

Smith, J dan Mangkoewidjojo. 1988. Pemeliharaan, Perbaikan dan Penggunaan Hewan Percobaan di Daerah Tropis. Jakarta: UI-Press

Sarwono, J. 2009. Paduan Lengkap Untuk Belajar Komputasi Statistik menggunakan SPSS 16. Yogyakarta: C.V ANDI OFFSET

Sudjana. 1980. Desain dan Analisis Eksperimen. Bandung: Tarsito.

Sugiyono. 2011. Metode Penelitian Kesehatan. Jakarta: Rineka Cipta.

Susila dan Suyanto.2014. Metode Penelitian Cross sectional kedokteran dan Kesehatan. Klaten: Bosscript.

Steenis, V. 1978.Flora Untuk Sekolah Indonesia, Jakarta: Pradaya Paramita.

Tresno, A.L. 2008.Bagian Giji RSCM \& Persatuan Ahli Giji Indonesia, Penuntun Diet. Agromedia Pustaka

Thenawidjaja, M. 1982. Dasar-dasar Biokimia. Jakarta: Erlangga.

Tisnadjaja, D., dkk., 2010. Pengkajian efekhiperkolesterolemik kapsul monasterol dan produksi senyawa bioaktif antidiabetes oleh kapang endofit dari tanaman obat Indonesia.Laporan Akhir Program Intensif Peneliti dan Perekayasa LIPI., 9-10.

Tjay, T.H dan Kirana. 2007. Obat-obat Penting Edisi ke enam cetakan pertama. Jakarta: PT Elex Media Komputindo.

Wash, T.D., 1997. Kapita Selekta Penyakit dan Terapi, Oleh Wijaya C., 195, 200-201, Buku Kedokteran ECG, Jakarta.

Yunila,W. 2013. 20 Buah Sakti Tumpas Berbagai Macam Penyakit. Yogyakarta: Buku Pintar 